\title{
Signs and symptoms in diagnosing acute myocardial infarction and acute coronary syndrome: a diagnostic meta-analysis
}

\author{
Rudi Bruyninckx, Bert Aertgeerts, Pieter Bruyninckx and Frank Buntinx
}

\begin{abstract}
Background

Prompt diagnosis of acute myocardial infarction or acute coronary syndrome is very important.

Aim

A systematic review was conducted to determine the accuracy of 10 important signs and symptoms in selected and non-selected patients.

Design of study

Diagnostic meta-analysis.

Method

Using MEDLINE, CINAHL, EMBASE, tracing references, and by contacting experts, studies were sought out that described one of the 10 signs and symptoms on one or both conditions. Studies were excluded if they were not based on original data. Validity was assessed using QUADAS and all data were pooled using a random effects model.

Results

Sixteen of the 28 included studies were about patients who were non-selected. In this group, absence of chest-wall tenderness on palpation had a pooled sensitivity of $92 \%(95 \%$ confidence interval $[\mathrm{Cl}]=86$ to 96) for acute myocardial infarction and $94 \%(95 \% \mathrm{Cl}=$ 91 to 96$)$ for acute coronary syndrome. Oppressive pain followed with a pooled sensitivity of $60 \%(95 \% \mathrm{Cl}$ $=55$ to 66) for acute myocardial infarction. Sweating had the highest pooled positive likelihood ratio ( $(\mathrm{R}+)$, namely $2.92(95 \% \mathrm{Cl}=1.97$ to 4.23$)$ for acute myocardial infarction. The other pooled LR+ fluctuated between 1.05 and 1.49. Negative LRs (LR-) varied between 0.98 and 0.23 . Absence of chest-wall tenderness on palpation had a LR- of $0.23(95 \% \mathrm{Cl}=$ 0.18 to 0.29 ).

Conclusions

Based on this meta-analysis it was not possible to define an important role for signs and symptoms in the diagnosis of acute myocardial infarction or acute coronary syndrome. Only chest-wall tenderness on palpation largely ruled out acute myocardial infarction or acute coronary syndrome in low-prevalence settings.

Keywords

diagnostic meta-analysis; myocardial ischemia; signs and symptoms.
\end{abstract}

\section{INTRODUCTION}

'Chest pain' is a symptom of illnesses of different organs (heart, lung, stomach and intestines, muscles, and skeleton) or of psychiatric disorders, all of which require specific treatment. Due to the high mortality and morbidity of coronary disease, in the event of chest pain, a GP will always consider the possibility of an acute myocardial infarction or unstable angina. Moreover, fast treatment - such as thrombolysis, percutaneous coronary intervention, or coronary artery bypass graft - can be life-saving and increase the patient's life expectancy and quality of life. ${ }^{1}$

The annual incidence of acute myocardial infarction for persons aged 30-69 years is estimated by the British Heart Foundation at $0.6 \%$ for men and at $0.1 \%$ for women. ${ }^{2}$ In Belgium the figures are comparable: in the 45-75-year-old age group Bartholomeeussen et $a l^{3}$ found a yearly incidence of acute myocardial infarction of $0.55 \%$ for men and $0.19 \%$ for women. The incidence of severe heart disease in people complaining of chest pain is highly dependent on the care setting: for Belgium percentages vary between $4.8 \%$ when a

R Bruyninckx, $M D, M S c, P h D$ student; B Aertgeerts, $M D$, $P h D$, professor; F Buntinx, $M D, P h D$, professor, Department of General Practice; P Bruyninckx, MSc, PhD student, Department of Medicine and Engineering, Katholieke Universiteit Leuven, Belgium.

\section{Address for correspondence}

Rudi Bruyninckx, Department of General Practice, KU Leuven, Kapucijnenvoer 33 Blok J, 3000 Leuven, Belgium.E-mail: rudi.bruyninckx@skynet.be

Submitted: 22 June 2007; Editor's response: 9 August 2007; final acceptance: 19 November 2007.

(C)British Journal of General Practice

This is the full-length article of an abridged version published in print. Cite this article as: Br J Gen Pract 2008; DOI: 10.3399/bjgp08X277014. 
GP is contacted and $24.2 \%$ for patients in the emergency department of a university teaching hospital. ${ }^{4}$

Severe prolonged chest pain of acute onset is rarely a decision-making problem. Attacks of chest pain that are experienced by the patient and defined as not very severe or prolonged, but distressing enough for them to contact a GP, present a more difficult problem in diagnosis and management. ${ }^{5}$ In the majority of European countries GPs will perform most of the triage in patients with chest pain and so can only rely on signs and symptoms. The accuracy of these signs and symptoms has already been the subject of systematic reviews. Several authors only used groups consisting of patients with known acute myocardial infarctions in their reviews; ${ }^{6-8}$ such studies can only determine the sensitivity. The specificity, the positive or negative likelihood ratio $(\mathrm{LR}+, \mathrm{LR}-)$, the positive predictive value (PPV), and the negative predictive value (NPV) cannot be determined using such samples. Consequently, the accuracy of a test cannot be described fully.

Panju et al only used studies concerning patients included via an emergency department or patients admitted to a hospital. ${ }^{9}$ Mant et al only used articles dated before 1992 in their review on signs and symptoms, ${ }^{10}$ while Chun and McGee only used MEDLINE for their search strategy. ${ }^{11}$ More recent studies were included in this systematic review. Two analyses were made: one of studies of patients who were non-selected (recruited by GPs, paramedics, or emergency departments) and one of studies of patients who were selected (recruited by coronary care units and cardiologists).

Ten signs and symptoms that could be found by history taking or physical examination were investigated. The diagnostic value was examined for acute myocardial infarction or acute coronary syndrome of:

- radiating pain (left arm and/or shoulder, right arm and/or shoulder, both arms and/or shoulder, neck, back, epigastric);

- oppressive pain;

- nausea and/or vomiting;

- sweating; and

- absence of chest-wall tenderness on palpation (absence of tenderness).

\section{METHOD}

\section{Search strategy}

MEDLINE, EMBASE and CINAHL were searched. All searches were up to date as of 31 May 2006. In MEDLINE a combination of terms was used involving all possible elements, the target disease

\section{How this fits in}

Most information about signs and symptoms is derived from studies in

coronary care units with patients who have $100 \%$ acute myocardial infarction.

Those data are not similarly accurate in a primary care setting (GP surgery,

emergency department, and paramedics). This study was not able to define an

important role for signs and symptoms in the diagnosis of acute myocardial

infarction or acute coronary syndrome. Only chest-wall tenderness on

palpation largely ruled out acute myocardial infarction or acute coronary

syndrome in low-prevalence settings.

and no filters: ("Physicians, Family"[MeSH] OR

"Emergency Service, Hospital"[MeSH] OR

"Emergency Medical Services"[MeSH] OR

"Emergency Medicine"[MeSH]) AND ("Chest Pain" [MeSH] OR "Myocardial Ischemia"[MeSH]).

An adapted version of this search string was used in CINAHL: ((Emergency-Medicine) OR (EmergencyService) OR (Physicians-Emergency) OR (Emergencies) OR (Emergency-Care) OR (Emergency-Medical-Services) OR (PhysiciansFamily) OR (Prehospital-Care)) AND ((AnginaPectoris) OR (Chest-Pain) OR (MyocardialInfarction) OR (Myocardial- Ischemia)).

The search string used in EMBASE was: ('emergency health service' OR 'general practitioner' OR 'emergency health service' OR 'emergency ward' OR 'emergency medicine') AND ('thorax pain' OR 'heart muscle ischemia')

In addition, the reference lists of the retrieved articles were checked. A search for any unpublished study results was limited to contacting known researchers in the field.

\section{Study selection}

The study strategy was designed to include all published diagnostic accuracy studies on signs and symptoms for the diagnosis of acute myocardial infarction, unstable angina, or acute coronary syndrome. Studies were excluded if diagnostic tests were not one of the 10 selected signs or symptoms and if they were not based on original data or if the data were insufficient to construct a 2x2 table. Language restrictions were English, French, German, and Dutch. Two independent reviewers screened the titles; a third reviewer resolved any disagreements that occurred between the two. All the selected titles were studied in full text by one reviewer. A list of excluded studies and a log of reasons for exclusion are available from the authors on request. When patients were recruited by GPs, paramedics, or emergency departments, they were considered 'non-selected'. Patients recruited by coronary care units and cardiologists 
Figure 1. Retrieval of eligible studies: flowchart. were considered 'selected'.

Chosen articles were retrieved in full and further included in the review after they had been assessed for quality using the QUADAS instrument, shown in Appendix 1. ${ }^{12}$ The selection of participants and the validity of the reference standard were the most important considerations. Studies were excluded from the review if they failed on one of these two items. Studies that failed on other QUADAS questions were not excluded, not even those without blind interpretation of the other tests, as blinding is almost impossible in this case.

\section{Data extraction}

The following data were extracted (in duplicate) from the studies:

- the design: whether the data were collected prospectively or retrospectively, and whether the participants were included consecutively;

- the setting: whether participants were recruited by GPs, cardiologists, paramedics, emergency departments, chest pain observation units, or coronary care units;

- age and sex;

- index test: pain radiating to left arm and/or shoulder; to right arm and/or shoulder; to both arms and/or shoulders; to neck; to back; epigastric, oppressive pain; nausea and/or vomiting; sweating; absence of tenderness;

- the number of patients and the prevalence of the disease in the study group;

- the results from the study in absolute numbers (in the absence of the absolute numbers, they were calculated from prevalence, sensitivity and specificity);

- the inclusion and exclusion criteria; and

- the reference standard.

\section{Statistical analysis and data synthesis}

Two groups were analysed separately: the patients who were non-selected and those who were selected. Standard methods recommended for the meta-analysis of diagnostic test evaluations were used. ${ }^{13-15}$ Analyses were performed using Stata (version 8, Stata Corporation, Texas). Sensitivity, specificity, LR+ (= sensitivity/[1 - specificity]; a positive test result makes the odds of the disease 'LR+' times more possible), LR- (= [1 sensitivity]/specificity; a negative test result makes the odds of the disease 'LR-' times less possible) and the odds ratio (OR) were pooled using a random effects model. PPV or NPV were not reported because of the heterogeneity between studies due to differences in setting and prevalence.

Heterogeneity in meta-analysis refers to the degree of variability in results across studies. Forest plots were examined and used, the $\chi^{2}$ and Fisher's Exact tests were used and, in view of the low power of the $\chi^{2}$ test, the $\mathrm{I}^{2}$ statistic was also estimated to detect heterogeneity..$^{16}$ In order to keep the tables readable, only the $\mathrm{I}^{2}$ data are reported. The potential presence of publication bias using funnel plots and the Egger test was tested for..$^{17-18}$

\section{RESULTS}

\section{Included studies}

Figure 1 outlines the study selection process. The great majority of publications concerning acute myocardial infarction and acute coronary syndrome discuss the technical tests and treatments. The number of studies found reporting the selected signs and symptoms was not very extensive there were 57 in all. A further 29 were excluded because only patients with confirmed acute myocardial infarctions or acute coronary syndromes 
were included. Twenty-eight articles were included in the meta-analysis: ${ }^{19-46} 16$ studies were about patients who were non-selected, 11 studies were about patients who were selected, and one study was made in a chest pain observation unit.

\section{Study characteristics and quality}

During the selection process the inter-rater agreement between the two reviewers was very good with a $\kappa$ of 0.82 (95\% confidence interval [Cl] $=0.79$ to 0.85 ). There was no disagreement in items of the QUADAS instrument. The results of the studies included on the QUADAS list are outlined in Appendix 2. In an attempt to analyse subgroups for sex and age, 14 authors were contacted by e-mail and additional data were obtained for two studies. Appendices 3 and 4 present the descriptive data from the studies included.

For the final diagnosis of acute myocardial infarction the reference tests used were enzyme rises $(n=23)$, electrocardiogram (ECG) change ( $n=$ $22)$, history $(n=11)$, scintigraphy $(n=8)$, autopsy ( $n$ $=5$ ), criteria of the World Health Organization or European Society of Cardiology $(n=4)$, sudden death $(n=3)$, coronary angiogram $(n=2)$, echocardiography $(n=2)$, or urgent revascularisation $(n=1)$. In some studies, at least two tests were required. History alone was always insufficient to diagnose an acute myocardial infarction.

Reference tests for unstable angina were: history (pain: frequency, worse, new) $(n=5)$, ECG changes without enzymes rises $(n=3)$, unproven acute myocardial infarction $(n=2)$, Canadian Cardiovascular Society classification criteria $(n=1)$, and clinical judgement $(n=1)$.

One study ${ }^{46}$ gave only reference tests for acute coronary syndrome: troponin rise, cardiac death, acute myocardial infarction, new onset heart failure, life-threatening arrhythmia, or coronary revascularisation.

\section{Prevalence}

Two large studies ${ }^{36,37}$ provided $50 \%$ of the subjects. When the results of all the studies were combined, there were 5067 (11.6\%) patients with acute myocardial infarction out of a group of 43138 , and $4594(26.3 \%)$ patients with acute coronary syndrome out of a group of 17416 . Of these 17416,13108 (75.3\%) belonged to a group also examined for acute myocardial infarction. There are approximately $50 \%$ more patients with unstable angina than acute myocardial infarction.

The varying prevalence of acute myocardial infarction depended on the setting and inclusion criteria. Graff et al's ${ }^{37}$ low prevalence of about $2 \%$ was caused by the very large inclusion criteria, that is, 'all patients with possible acute myocardial infarction for whom a rapid ECG was performed'. The chest pain observation unit, to which patients with unclear signs and symptoms and without clear ECG abnormalities and/or blood abnormalities were admitted, had a prevalence of $4 \% .{ }^{40}$ In other studies executed in emergency departments, prevalences of between $6 \%$ and $18 \%$ were found. The group transported by ambulance in Svenson et al's study, ${ }^{44}$ with a prevalence of $29 \%$, situates itself between the patients seen in an emergency department and those admitted to a coronary care unit (prevalence from 36-50\%). In the study of Van der Does et $a^{21}$ the prevalence of referred patients was as low as $7 \%$.

\section{Heterogeneity in the non-selected group}

For acute myocardial infarction there was homogeneity in the LR+ of oppressive pain and in the LR- for tenderness. For acute coronary syndrome there was homogeneity in the LR+ of leftarm pain and the LR- for sweating and tenderness. For the other analyses, a moderate to high level of heterogeneity was found.

\section{Indications of diagnostic accuracy in the non-selected group}

Appendix 5 (for the diagnosis of acute myocardial infarction) and Appendix 6 (for a diagnosis acute coronary syndrome) (both subgroups separately) show the pooled sensitivity, specificity, LR+, LR-, and OR with their $95 \% \mathrm{Cl}$ and $\mathrm{I}^{2}$. The sensitivity and specificity per sign or symptom varied greatly.

The sensitivity of absence of tenderness was

Figure 2. Funnel plot for evaluation of publication bias in all studies.

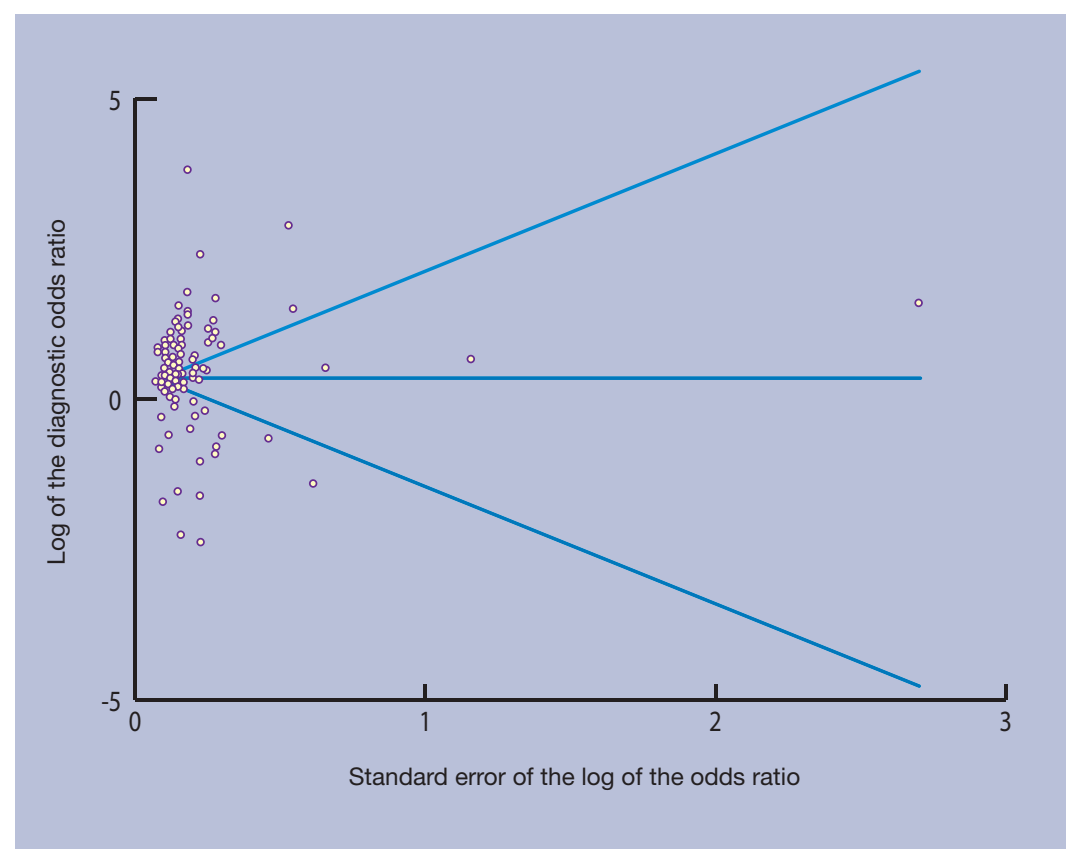


high, namely $92 \%(95 \% \mathrm{Cl}=85.5$ to 96.4$)$ for acute myocardial infarction and $94 \%(95 \% \mathrm{Cl}=91.4$ to 96.1) for acute coronary syndrome. Oppressive pain followed with a sensitivity of $60 \%(95 \% \mathrm{Cl}=53.7$ to 66.0 for acute myocardial infarction). Sweating had the highest LR+, namely $2.92(95 \% \mathrm{Cl}=1.97$ to 4.32 for acute myocardial infarction).

The LR+ of right arm or shoulder pain was 2.89 $(95 \% \mathrm{Cl}=1.40$ to 5.98$)$ for acute myocardial infarction (one study). The other LR+ fluctuated between 1.05 and 1.49 for acute coronary syndrome.

Absence of tenderness had a LR- of $0.23(95 \% \mathrm{Cl}$ $=0.18$ to 0.29$)$ for acute myocardial infarction and $0.17(95 \% \mathrm{Cl}=0.11$ to 0.26$)$ for acute coronary syndrome. Other LR- varied between 0.69 (oppressive pian and sweating for acute myocardial infarction) and 0.98 (epigastric pain) for acute coronary syndrome.

\section{Publication bias}

A funnel plot, signifying publication bias, is shown in Figure 2. The plot appears symmetrical, suggesting absence of publication bias. This was confirmed by a non-significant Egger test (0.79).

\section{DISCUSSION}

\section{Studies included}

More than half of the studies dated from after Mant et al's ${ }^{10}$ selection. Sixteen new articles about several signs and symptoms that were not included in Chun and McGee's review ${ }^{11}$ were included, indicating the necessity for a new systematic review.

Although the authors aimed to find all relevant studies, some could have been missed. However, the search strategy will have detected most studies. As only two studies were performed in a general practice setting, it was decided to look for 'primary care' studies, which were defined as settings in which patients who had not been referred by other medical practitioners were seen. In Europe and some other parts of the world this mostly concerns general practice. In the US and a number of other countries however, this frequently includes the emergency department and patients admitted by paramedics. The information on these unselected patients is certainly relevant for GPs.

\section{Quality}

A fair amount of research dates from several decades ago. It could be argued that these older studies are disadvantaged in terms of quality as empirical research on design-related bias and the STARD (Standards for Reporting of Diagnostic Accuracy) initiative to improve quality are fairly recent. ${ }^{47-49}$ Although new research on the quality of diagnostic accuracy studies confirms that quality is still not optimal, the quality of the studies included was good according to the QUADAS criteria.

A good reference test is essential in diagnostic research. It was unclear how frequently these criteria were used for the definite diagnosis of acute myocardial infarction. The acceptance of a broad range of inclusion criteria (autopsy, sudden death, scintigraphy, echocardiography, and angiography) as reference tests increased the number of real positives at the risk of spectrum bias. ${ }^{10}$ Verification bias was not a major problem because almost all patients received a reference standard. The increasing sensitivity of the blood tests used over the years - starting with transaminase via lactate dehydrogenase, creatine kinase $(\mathrm{CK})$ and the isoenzyme CK-MB, and recently troponin $\mathrm{T}$ - has caused a rise in real positives. However, no increase in the prevalence of acute myocardial infarction in the emergency departments or the coronary care units was noticed over the course of time. The reference test for unstable angina was not as clearly defined as that for acute myocardial infarction because it often depended on the clinical picture and its interpretation. All of this could cause either over- or underestimation of the prevalence found.

Although 'acute myocardial infarction + unstable angina = acute coronary syndrome', a distinction was made between acute myocardial infarction and acute coronary syndrome to ensure that no data was left out of those studies that dealt only with acute myocardial infarction.

\section{Prevalences}

In 2000, the definition of acute myocardial infarction changed to: 'typical rise and gradual fall of cardiac troponin, or more rapid fall of CK-MB, with at least one of the following: ischemic symptoms; the development of pathological $Q$ waves; ECG changes indicative of ischemia (ST-segment elevation or depression); coronary artery intervention'. ${ }^{50}$ This definition of acute myocardial infarction will increase the sensitivity of diagnosing acute myocardial infarction and thereby increase the findings of its incidence. The increased specificity of troponin, however, should decrease the number of false-positive diagnoses. The combined effect that these two factors may have on the case-fatality rate is currently unclear. ${ }^{51}$

The larger number of acute myocardial infarctions in patients transported by ambulance compared to those in patients transported to the emergency department by other means has been documented previously. ${ }^{4}$ The low prevalence of referred patients in the study by van der Does et $a{ }^{21}$ is possibly 
explained by the underestimation of the number of acute myocardial infarctions due to the absence of sensitive blood analyses in 1972.

It should also be noted that in most studies the true population prevalence of acute myocardial infarction was higher because patients who died at home could not be included.

\section{Heterogeneity}

Most of the pooled results were heterogeneous, due to different settings, inclusion criteria, and reference standards. The non-homogenous pooled results must be interpreted very carefully.

\section{Diagnostic accuracy of signs and symptoms in the non-selected patients group}

Absence of tenderness was highly sensitive for acute myocardial infarction (92\%) and acute coronary syndrome (94\%). The presence of palpation pain greatly reduces the chance of acute myocardial infarction and acute coronary syndrome with a LR- of 0.23 and 0.17 respectively. Similar pleuretic or positional thoracic pain was not selected in this study. In Mant's et al's study the absence of pleuretic pain had a LR- of 0.19 and the absence of positional pain a LR- of $0.27 .{ }^{10}$ Oppressive pain, with a pooled sensitivity of $60 \%$ and a specificity of $58 \%$ has almost no influence on the likelihood of acute myocardial infarction. The sensitivities of the other signs and symptoms were even lower and could not be used to exclude acute myocardial infarction or acute coronary syndrome. The differences in sensitivity and specificity between acute myocardial infarction and acute coronary syndrome remained small and were therefore not relevant.

It is true that, even in unselected settings such as general practice, patients have a reason for visiting their GP with chest pain. Fear of having a myocardial infarction may be one such reason. Anyone not visiting their doctor will not be diagnosed with acute myocardial infarction so the classical signs and symptoms of chest pain and irradiation are always part of the diagnostic workup.

\section{Clinical implications}

To summarise the interpretation of signs and symptoms in the clinical context, consider a patient in a low-, intermediate-, and high-prevalence setting. For the sake of clarity the highest pooled $\mathrm{LR}+$ and the lowest LR- found for acute myocardial infarction, namely sweating ( $L R+2.92$, LR- 0.69), and absence of chest-wall tenderness (LR+1.47, LR- 0.23) were used.

In a low pre-test probability situation of $5 \%$, which may be regarded as the prevalence in those patients who are unselected and contact a GP with chest pain, these LR+ translate to a $13 \%$ and $7 \%$ post-test probability of a positive test result. ${ }^{4}$ In low pre-test settings the presence of the signs and symptoms listed above is insufficient to definitively confirm acute myocardial infarction. In their absence the post-test probability is lowered to $4 \%$ and $1 \%$. Absence of sweating should scarcely affect GPs' management; the presence of chestwall tenderness results in a post-test probability of $1.1 \%$ and so largely rules out acute myocardial infarction for clinical purposes.

In an intermediate-prevalence setting of $15 \%$, which is the prevalence expected in a patient seen by the GP during an urgent home visit or in an emergency department, the same reasoning produces a post-test probability of $34 \%$ and $21 \%$. If these symptoms are absent this becomes $11 \%$ and $4 \%$. These results should barely influence GPs' treatment strategy.

In a high-prevalence setting of $40 \%$, such as a coronary care unit the same signs or symptoms represent a post-test probability of $66 \%$ and $49 \%$ if positive, and $32 \%$ and $13 \%$ if negative. These results will also add nothing to the diagnostic process.

Each of these signs and symptoms may also trigger consideration of acute myocardial infarction or acute coronary syndrome: non-specific complaints such as back pain or vomiting/nausea can also be caused by acute myocardial infarction or acute coronary syndrome. In Goodacre et al's ${ }^{45}$ study of patients with undifferentiated chest pain (with normal ECG and without a clear clinical diagnosis of acute coronary syndrome) the final diagnosis was acute coronary syndrome in $7.9 \%$. This group of missed acute coronary syndrome probably still has a higher mortality than patients without acute coronary syndrome. ${ }^{52}$

\section{Previous meta-analyses of signs and symptoms}

All the pooled results were situated within the 95\% Cls of the previous investigations, except in the absence of chest-wall tenderness. Here a LR+ of $1.47(95 \% \mathrm{Cl}=1.23$ to 1.75$)$ was found, which was somewhat higher than in Mant et al's ${ }^{10}$ research (1.18; $95 \% \mathrm{Cl}=1.16$ to 1.22 ).

\section{Limitations of the review}

Some studies suggested a difference in the diagnostic accuracy of signs and symptoms according to age ${ }^{27,38}$ or sex, ${ }^{43}$ but there were not enough studies to perform a subgroup analysis. Although the combination of signs and symptoms, 
their context, the severity, and the progression from the start influence the interpretation, it was impossible to examine this because there were almost no included studies that investigated the diagnostic accuracy of combinations of signs and symptoms. Only three of the selected studies combined different signs and symptoms: Short ${ }^{22}$ (previous or not-previous history of acute coronary syndrome and studied signs and symptoms), Lee et $a^{23}$ (sharp or stabbing pain and pain pleuretic, positional or reproduced by palpation and no prior acute coronary syndrome), and Hargarten et $a /^{25}$ (radiating pain and sweating, difficult breathing, and nausea/vomiting).

Persons with chest pain can also be subject to serious, even life-threatening, diseases other than acute myocardial infarction or acute coronary syndrome, such as pulmonary embolism, and stomach bleeding. This requires analysis with CART-type models in the individual studies. CART is a statistical package that produces decision trees using variables (coded signs and symptoms) directing to classes (diagnostic categories). At each node of the decision tree, the programme calculates which variable is the 'most discriminating' and constructs, at that node, a bifurcation of two branches. For each resulting branch, CART calculates the next most discriminating variable and continues in this way until either the subgroups or the discriminating power become 'too small'. A final statistical pruning technique results in an optimal tree, where optimality is measured by various criteria..$^{53-55}$ As far as the authors know no systematic review has been published pooling the results of such studies.

In 2005 a new multilevel method for the bivariate pooling of combined sensitivity and specificity was published. ${ }^{56}$ This method may be superior to classic pooling. The authors were asked to do the calculations on the current study's results of the absence of chest-wall tenderness on palpation in relation to acute myocardial infarction. Because of the minimal differences, the previous calculations were not reworked.

\section{Conclusions}

Based on this meta-analysis, it was not possible to define an important role for signs and symptoms in the diagnosis of acute myocardial infarction or acute coronary syndrome. Only chest-wall tenderness on palpation largely ruled out acute myocardial infarction or acute coronary syndrome in low-prevalence settings.

\section{Competing interests}

The authors have stated that there are none

\section{Acknowledgements}

We are grateful to the authors of the primary studies who sent additional data as well as Dr Johannes Reitsma for doing the bivariate analysis of combined sensitivity and specificity

\section{Discuss this article}

Contribute and read comments about this article on the Discussion Forum: http://www.rcgp.org.uk/bjgp-discuss

\section{REFERENCES}

1. Boersma E, Maas AC, Deckers JW, Simoons M. Early thrombolytic treatment in acute myocardial infarction: re-appraisal of the golden hour. Lancet 1996; 348(9030): 771-775.

2. British Heart Foundation. British Heart Foundation Statistics Database. www.heartstats.org (accessed 3 Jan 2008)

3. Bartholomeeussen S, Truyers C, Buntinx F. Ziekten in de huisartspraktijk in Vlaanderen. [Diseases in General Practices in Flanders.] Leuven: Academisch Centrum voor Huisartsgeneeskunde, 2004.

4. Buntinx F, Knockaert D, Bruyninckx R, et al. Chest pain in general practice or in the hospital emergency department: is it the same? Fam Pract 2001; 18(6): 586-589.

5. Erhardt L, Herlitz J, Bossaert L, et al. Task force on the management of chest pain. Eur Heart J 2002; 23(15): 1153-1176.

6. DeVon H, Zerwic J. Symptoms of acute coronary syndromes: are there gender differences? A review of the literature. Heart Lung 2002; 31(4): 235-245.

7. Chen W, Woods S, Puntillo K. Gender differences in symptoms associated with acute myocardial infarction: a review of the research. Heart Lung 2005; 34(4): 240-247.

8. Swap CJ, Nagurney JT. Value and limitations of chest pain history in the evaluation of patients with suspected acute coronary syndromes. JAMA 2005; 294(20): 2623-2629.

9. Panju A, Hemmelgarn B, Guyatt G, Simel D. The rational clinical examination. Is this patient having a myocardial infarction? JAMA 1998; 280(14): 1256-1263.

10. Mant J, McManus R, Oakes R, et al. Systematic review and modelling of the investigation of acute and chronic chest pain presenting in primary care. Health Technol Assess 2004; 8(2): iii, $1-158$.

11. Chun A, McGee S. Bedside diagnosis of coronary artery disease: a systematic review. Am J Med 2004; 117(5): 334-343.

12. Whiting P, Rutjes AW, Reitsma JB, et al. The development of QUADAS: a tool for the quality assessment of studies of diagnostic accuracy included in systematic reviews. BMC Med Res Methodol 2003; 3: 25.

13. Devillé W, Buntinx F, Bouter L, et al. Conducting systematic reviews of diagnostic studies: didactic guidelines. BMC Med Res Methodol 2002; 2: 9 .

14. Cochrane Methods Group on Systematic Review of Screening and Diagnostic Tests: recommended methods. Cochrane Collaboration 1996. http://www.cochrane.org/docs/sadtdocl.htm (accessed 4 Jan 2008).

15. Deeks JJ. Systematic reviews in health care: systematic reviews of evaluations of diagnostic and screening tests. BMJ 2001; 323(7305): 157-162.

16. Higgins JP, Thompson SG, Deeks JJ, Altman DG. Measuring inconsistency in meta-analyses. BMJ 2003; 327(7414): 557-560

17. Song F, Khan KS, Dinnes J, Sutton AJ. Asymmetric funnel plots and publication bias in meta-analyses of diagnostic accuracy. Int $J$ Epidemiol 2002; 31(1): 88-95.

18. Egger M, Davey Smith G, Schneider M, Minder C. Bias in metaanalysis detected by a simple, graphical test. BMJ 1997; 315(7109): 629-634.

19. Säwe U. Pain in acute myocardial infarction. A study of 137 patients in a coronary care unit. Acta Med Scand 1971; 190(1-2): 79-81.

20. Säwe U. Early diagnosis of acute myocardial infarction with specia reference to the diagnosis of the intermediate coronary syndrome. A clinical study. Acta Med Scand Suppl 1972; 545: 1-76.

21. Van der Does E, Lubsen J, Pool J. Acute myocardial infarction: an easy diagnosis in general practice? J R Coll Gen Pract 1980; 30(216): 405-409.

22. Short D. Diagnosis of slight and subacute coronary attacks in the 
community. Br Heart J 1981; 45(3): 299-310.

23. Lee T, Cook F, Weisberg M, et al. Acute chest pain in the emergency room. Identification and examination of low-risk patients. Arch Intern Med 1985; 145(1): 65-69.

24. Tierney WM, Fitzgerald J, McHenry R, et al. Physicians' estimates of the probability of myocardial infarction in emergency room patients with chest pain. Med Decis Making 1986; 6(1): 12-17.

25. Hargarten KM, Aprahamian C, Stueven H, et al. Limitations of prehospital predictors of acute myocardial infarction and unstable angina. Ann Emerg Med 1987; 16(12): 1325-1329.

26. Herlihy T, McIvor M, Cummings CC, et al. Nausea and vomiting during acute myocardial infarction and its relation to infarct size and location. Am J Cardiol 1987; 60(1): 20-22.

27. Solomon CG, Lee TH, Cook EF, et al. Comparison of clinical presentation of acute myocardial infarction in patients older than 65 years of age to younger patients: the Multicenter Chest Pain Study experience. Am J Cardiol 1989; 63(12): 772-776.

28. Berger JP, Buclin T, Haller E, et al. Right arm involvement and pain extension can help to differentiate coronary diseases from chest pain of other origin: a prospective emergency ward study of 278 consecutive patients admitted for chest pain. J Intern Med 1990; 227(3): 165-172.

29. Jonsbu J, Rollag A, Aase O, et al. Rapid and correct diagnosis of myocardial infarction: standardized case history and clinical examination provide important information for correct referral to monitored beds. J Intern Med 1991; 229(2): 143-149.

30. Gaston-Johansson F, Hofgren C, Watson P, Herlitz J. Myocardial infarction pain: systematic description an analysis. Intensive Care Nurs 1991; 7(1): 3-10

31. Hartford M, Karlson B, Sjölin M, et al. Symptoms, thoughts, an environmental factors in suspected acute myocardial infarction. Heart Lung 1993; 22(1): 64-70.

32. Grijseels EW, Deckers JW, Hoes AW, et al. Pre-hospital triage of patients with suspected myocardial infarction: evaluation of previously developed algorithms and new proposals. Eur Heart $J$ 1995; 16(3): 325-332.

33. Everts B, Karlson B, Wahrborg P, et al. Localization of pain in suspected acute myocardial infarction in relation to final diagnosis age and sex, and site and type of infarction. Heart Lung 1996; 25(6): 430-437.

34. Pfister R, Gaillet R, Saner H, et al. Die Vorspitalphase von Patienten mit Verdacht auf akuten Myokardinfarkt: Ergebnisse der 'Oltner Herznotfallstudie'. [The prehospital phase of patients with suspected acute myocardial infarct: results of the Oltner Cardiac Emergency Study]. Schweiz Med Wochenschr 1997; 127(12): 479-488.

35. Lopez-Jiminez F, Goldman L, Johnson PA, et al. Effect of diabetes mellitus on the presentation and triage of patients with acute chest pain without known coronary artery disease. Am J Med 1998; 105(6): 500-505.

36. Pope JH, Ruthazer R, Beshansky JR, et al. Clinical features of emergency department patients presenting with symptoms suggestive of acute cardiac ischemia: a multicenter study. J Thromb Thrombolysis 1998; 6(1): 63-74.

37. Graff L, Palmer AC, LaMonica P, Wolf S. Triage of patients for a rapid (5-minute) electrocardiogram: a rule based on presenting chief complaints. Ann Emerg Med 2000; 36(6): 554-560.

38. Milner KA, Funk M, Richards S, et al. Symptom predictors syndromes in younger and older patients. Nurs Res 2001; 50(4): 233-241.
39. Herlitz J, Starke M, Hansson E, et al. Early identification of patients with an acute coronary syndrome as assessed by dispatchers and the ambulance crew. Am J Emerg Med 2002; 20(3): 196-201.

40. Goodacre S, Locker T, Morris F, Campbell S. How useful are clinical features in the diagnosis of acute, undifferentiated chest pain? Acad Emerg Med 2002; 9(3): 203-208.

41. Baxt WG, Shofer FS, Sites FD, Hollander JE. A neural computational aid to the diagnosis of acute myocardial infarction. Ann Emerg Med 2002; 39(4): 366-373.

42. Albarran J, Durham B, Gowers J, et al. Is the radiation of chest pain a useful indicator of myocardial infarction? A prospective study of 541 patients. Accid Emerg Nurs 2002; 10(1): 2-9.

43. Vodopiutz J, Poller S, Schneider B, et al. Chest pain in hospitalized patients: cause-specific and gender specific differences. J Women Health (Larchmt) 2002; 11(8): 719-727.

44. Svensson L, Isaksson L, Axelsson C, et al. Predictors of myocardial damage prior to hospital admission among patients with acute chest pain or other symptoms raising a suspicion of acute coronary syndrome. Coron Artery Dis 2003; 14(3): 225-231.

45. Goodacre SW, Angelini K, Arnold J, et al. Clinical predictors of acute coronary syndromes in patients with undifferentiated chest pain. Q J Med 2003; 96(12): 893-898.

46. Christenson J, Innes $\mathrm{G}, \mathrm{McKnight} \mathrm{D}$, et al. A clinical rule for early discharge of patients with chest pain. Ann Emerg Med 2006; 47(1): $1-10$.

47. Reid MC, Lachs MS, Feinstein AR. Use of methodological standards in diagnostic test research. Getting better but still not good. JAMA 1995; 274(8): 645-651.

48. Lijmer JG, Mol BW, Heisterkamp S, et al. Empirical evidence of design-related bias in studies of diagnostic tests. JAMA 1999 282(11): 1061-1066.

49. Bossuyt PM, Reitsma JB, Bruns DE, et al. Towards complete and accurate reporting of studies of diagnostic accuracy: the STARD initiative. BMJ 2003; 326(7379): 41-44.

50. Alpert IS, Thygesen K, Antman E, Bassand JP. Myocardial infarction redefined - a consensus document of The Joint European Society of Cardiology/American College of Cardiology Committee for the redefinition of myocardial infarction. J Am Coll Cardiol 2000; 36(3): 959-969.

51. Newby LK, Alpert JS, Ohman EM, Thygesen K, Califf RM. Changing the diagnosis of acute myocardial infarction: implications for practice and clinical investigations. Am Heart J 2002; 144(6): 957-980.

52. Sanchis J, Bodí V, Nunez J, et al. New risk score for patients with acute chest pain, non-ST-segment deviation, and normal troponin concentrations: a comparison with the TIMI risk score. J Am Coll Cardiol 2005; 46(3): 443-449.

53 Buntinx F, Truyen J, Embrechts P, et al. Evaluating patients with chest pain using classification and regression trees. Fam Pract 1992; 9(2): 149-153.

54 Marshall RJ. The use of classification and regression trees in clinical epidemiology. J Clin Epidemiol 2001; 54(6): 603-609.

55 Van den Bruel A, Aertgeerts B, Bruyninckx R, et al. Signs and symptoms for diagnosis of serious infections in children: a prospective study in primary care. Br J Gen Pract 2007; 57(540): $538-546$

56. Reitsma JB, Glas AS, Rutjes AW, et al. Bivariate analysis of sensitivity and specificity produces informative summary measures in diagnostic reviews. J Clin Epidemiol 2005; 58(10): 982-990. 


\section{Appendix 1. The QUADAS tool. ${ }^{12}$}

Was the spectrum of patients representative of patients who will receive the test in practice?

- Were selection criteria clearly described?

Is the reference standard likely to correctly classify the target condition?

Is the time period between reference standard and index test short enough to be reasonably sure that the target condition did not change between the two tests?

- Did the whole sample or a random selection of sample receive verification using a reference standard diagnosis?

Did patients receive the same reference standard regardless of the index test result?

Was the reference standard independent of the index test (that is, the index test did not form part of the reference standard?)

Was the execution of the index test described in sufficient detail to permit replication of the test?

- Was the execution of the reference standard described in sufficient detail to permit its replication?

Were the index test results interpreted without knowledge of the results of the reference standard?

- Were the reference standard results interpreted without knowledge of the results of the index test?

- Were the same clinical data available when test results were interpreted as would be available when the test is used in practice?

Were interpretable intermediate test results reported?

Were withdrawals from the study explained? 
Appendix 2. Qualification of the articles with the QUADAS tool.

\begin{tabular}{|c|c|c|c|c|c|c|c|c|c|c|c|c|c|c|}
\hline & 1 & 2 & 3 & 4 & 5 & 6 & 7 & 8 & 9 & 10 & 11 & 12 & 13 & 14 \\
\hline Säwe, $1971^{19}$ & yes & yes & yes & yes & yes & yes & yes & yes & yes & $?$ & $?$ & yes & yes & no \\
\hline Säwe, $1972^{20}$ & yes & yes & yes & yes & yes & yes & yes & yes & yes & $?$ & $?$ & yes & yes & no \\
\hline Van der Does, $1980^{21}$ & yes & yes & yes & yes & yes & yes & yes & yes & yes & yes & no & yes & yes & yes \\
\hline Short, $1981^{22}$ & yes & yes & yes & no & yes & yes & yes & no & yes & yes & no & yes & yes & yes \\
\hline Lee, $1985^{23}$ & yes & yes & yes & yes & yes & yes & yes & yes & yes & yes & $?$ & yes & no & no \\
\hline Tierney, $1986^{24}$ & yes & yes & yes & yes & yes & yes & yes & yes & yes & yes & yes & yes & yes & no \\
\hline Hargarten, $1987^{25}$ & yes & yes & yes & yes & yes & yes & yes & yes & no & $?$ & no & yes & no & no \\
\hline Herlihy, $1987^{26}$ & yes & yes & yes & yes & yes & yes & yes & yes & yes & $?$ & $?$ & yes & no & yes \\
\hline Solomon, $1989^{27}$ & yes & yes & yes & yes & yes & yes & yes & yes & yes & yes & $?$ & yes & no & yes \\
\hline Berger, $1990^{28}$ & yes & no & yes & yes & yes & yes & yes & yes & yes & yes & $?$ & yes & yes & no \\
\hline Jonsbu, $1991^{29}$ & yes & yes & yes & yes & yes & yes & yes & yes & yes & yes & $?$ & yes & no & no \\
\hline Gaston-Johansson, $1991^{30}$ & yes & no & yes & yes & yes & yes & yes & yes & yes & $?$ & $?$ & yes & no & no \\
\hline Grijseels, $1995^{32}$ & yes & yes & yes & yes & yes & yes & yes & yes & yes & yes & $?$ & yes & no & yes \\
\hline Everts, $1996^{33}$ & yes & no & yes & yes & yes & yes & yes & yes & yes & $?$ & $?$ & yes & no & no \\
\hline Pfister, $1997^{34}$ & yes & yes & yes & yes & yes & yes & yes & no & no & yes & no & yes & no & yes \\
\hline Lopez-Jiminez, $1998^{35}$ & yes & yes & yes & yes & yes & yes & yes & yes & yes & yes & yes & yes & no & no \\
\hline Pope, $1998^{36}$ & yes & yes & yes & yes & yes & yes & yes & yes & yes & $?$ & $?$ & yes & yes & no \\
\hline Graff, $2000^{37}$ & yes & yes & no & yes & $?$ & $?$ & yes & yes & no & $?$ & $?$ & yes & no & no \\
\hline Milner, $2001^{38}$ & yes & yes & yes & yes & yes & yes & yes & yes & yes & $?$ & yes & yes & no & yes \\
\hline Herlitz, $2002^{39}$ & yes & yes & yes & yes & yes & yes & yes & yes & yes & yes & $?$ & yes & no & no \\
\hline Goodacre, $2002^{40}$ & yes & yes & yes & yes & yes & yes & yes & yes & yes & yes & $?$ & yes & no & yes \\
\hline Baxt, $2002^{41}$ & yes & yes & yes & yes & yes & yes & yes & yes & yes & $?$ & $?$ & yes & yes & no \\
\hline Albarran, $2002^{42}$ & yes & yes & yes & yes & yes & yes & yes & yes & yes & $?$ & $?$ & yes & no & no \\
\hline Vodopiutz, $2002^{43}$ & yes & yes & yes & yes & yes & yes & yes & yes & yes & $?$ & $?$ & yes & no & yes \\
\hline Christenson, $2006^{46}$ & yes & yes & yes & yes & yes & yes & yes & yes & yes & yes & yes & yes & yes & yes \\
\hline
\end{tabular}


Appendix 3. Characteristics of acute myocardial infarction (AMI) included studies.

\begin{tabular}{|c|c|c|c|c|c|c|c|c|c|}
\hline Study & Design & $\begin{array}{l}\text { Sample } \\
\text { size }\end{array}$ & $\% \mathrm{AMI}$ & $\begin{array}{l}\text { Mean } \\
\text { age }\end{array}$ & $\%$ males & Setting & Inclusion & Exclusion & $\begin{array}{c}\text { Reference } \\
\text { standard AMI }\end{array}$ \\
\hline Säwe, $1971^{19, a}$ & $\begin{array}{l}\text { Prospective } \\
\text { consecutive }\end{array}$ & 137 & 39 & 62 & 67 & $\mathrm{CCU}$ & $\begin{array}{l}\text { Central chest pain } \\
(>15 \mathrm{~m},<48 \mathrm{hr} \text { ) or } \\
\text { pulmonary oedema } \\
\text { or shock or syncope } \\
\text { or status anginosus }\end{array}$ & $\begin{array}{l}\text { Known valvular lesion, } \\
\text { acute hypovolaemia or } \\
\text { intoxication, syncope } \\
\text { without ECG } \\
\text { evidence of AMI }\end{array}$ & $\begin{array}{l}\text { Q-wave and/or } \\
\text { or } \text { ST elevation or } \\
\text { GOT, GPT, LDH } \\
\text { changes, necropsy }\end{array}$ \\
\hline Säwe, $1972^{20, a}$ & $\begin{array}{l}\text { Prospective } \\
\text { consecutive }\end{array}$ & 921 & 49 & 65 & 60 & $\mathrm{CCU}$ & $\begin{array}{l}\text { Central chest pain } \\
\text { (>15 } \mathrm{m},<48 \mathrm{hr} \text { ) or } \\
\text { pulmonary oedema } \\
\text { or shock or syncope } \\
\text { or status anginosus }\end{array}$ & $\begin{array}{c}\text { Known valvular lesion, } \\
\text { acute hypovolaemia } \\
\text { or intoxication, } \\
\text { syncope } \\
\text { without ECG } \\
\text { evidence of AMI }\end{array}$ & $\begin{array}{l}\text { Q-wave and/or } \\
\text { ST elevation or } \\
\text { GOT, GPT, LDH } \\
\text { changes or autopsy } \\
\text { findings myocardial } \\
\text { necrosis }\end{array}$ \\
\hline $\begin{array}{l}\text { Van der Does, } \\
\text { et al, } 1980^{21}\end{array}$ & $\begin{array}{l}\text { Prospective } \\
\text { consecutive }\end{array}$ & 1343 & 7 & 54 & 55 & GP & $\begin{array}{l}\text { Recent chest pain } \\
\text { or dyspnoea, } \\
\text { palpitations or } \\
\text { dizziness or syncope } \\
\text { upper abdominal pain } \\
\text { or mood changes }\end{array}$ & $\begin{array}{l}<25 \mathrm{yr} \text { women, } \\
<20 \mathrm{yr} \text { men }\end{array}$ & $\begin{array}{l}\text { WHO criteria for AMI, } \\
\text { at least } 4 \text { pts score: } \\
\text { ECG typical-2pt, } \\
\text { suspect-1pt, ditto } \\
\text { symptoms and } \\
\text { enzymes }\end{array}$ \\
\hline Short, $1981^{22}$ & Prospective? & 456 & 40 & 62 & 57 & Car & $\begin{array}{l}\text { One or more attacks } \\
\text { of spontaneous } \\
\text { chest pain and who } \\
\text { were referred for } \\
\text { cardiology opinion }\end{array}$ & $\begin{array}{l}\text { III enough for } \\
\text { hospitalisation or } \\
\text { diagnosis of coronary } \\
\text { disease regarded } \\
\text { as definite }\end{array}$ & $\begin{array}{c}\text { History and ECG } \\
\text { (Minnesota code) } \\
\text { y or twice limit AAT } \\
\text { at } 24-48 \mathrm{hr} \\
\text { after onset }\end{array}$ \\
\hline $\begin{array}{l}\text { Lee, et al, } \\
1985^{23}\end{array}$ & $\begin{array}{l}\text { Prospective } \\
\text { consecutive }\end{array}$ & 596 & 17 & 56 & 48 & ED & $\begin{array}{l}\text { Chief complaint of } \\
\text { anterior, precordial or } \\
\text { left lateral chest pain }\end{array}$ & $\begin{array}{c}\text { Local trauma, } \\
\text { abnormalities on } \\
\text { chest X-ray, <25 yr }\end{array}$ & $\begin{array}{c}\text { One of: characteristic } \\
\text { evolution of enzyme } \\
\text { levels (CK-MB } \\
\text { or LDH or CK) or } \\
\text { Q-waves } \\
\text { of scintiscan }\end{array}$ \\
\hline
\end{tabular}

\begin{tabular}{|c|c|c|c|c|c|c|c|c|c|}
\hline $\begin{array}{l}\text { Tierney, et al, } \\
1986^{24}\end{array}$ & Prospective? & 492 & 12 & $?$ & $?$ & ED & $\begin{array}{l}\text { Anterior chest pain } \\
\text { as one of their } \\
\text { complaints }\end{array}$ & $\begin{array}{l}<30 \text { yr men, } \\
<40 \text { yr female }\end{array}$ & $\begin{array}{l}\text { When cardiac enzyme } \\
\text { CK elevated } \\
\text { and CK-MB } \\
>4 \% \text { or LDH1> (or } \\
\text { equal) LDH or when } \\
\text { no enzyme: new } \\
\text { abnormal Q-wave }\end{array}$ \\
\hline $\begin{array}{l}\text { Herlihy, et al, } \\
1987^{26}\end{array}$ & $\begin{array}{l}\text { Prospective } \\
\text { consecutive }\end{array}$ & 265 & 44 & $?$ & $?$ & $\mathrm{CCU}$ & $\begin{array}{l}\text { Chest pain and } \\
\text { electrographic } \\
\text { changes }\end{array}$ & \multicolumn{2}{|c|}{$\begin{array}{l}\text { Illness or medication } \\
\text { that could produce } \\
\text { nausea, with } \\
\text { thrombolytic medication }\end{array}$} \\
\hline $\begin{array}{l}\text { Solomon, et al, } \\
1989^{27}\end{array}$ & $\begin{array}{l}\text { Prospective } \\
\text { consecutive }\end{array}$ & 7734 & 14 & $?$ & 50 & ED & $\begin{array}{l}\text { Chief complaint of } \\
\text { anterior, precordial } \\
\text { or left lateral } \\
\text { chest pain }\end{array}$ & $\begin{array}{l}\text { Local trauma, } \\
\text { abnormalities on } \\
\text { chest X-ray, } \\
<30 \text { yr, >4 visit }\end{array}$ & $\begin{array}{c}\text { One of: } \\
\text { characteristics } \\
\text { evolution of } \\
\text { enzyme levels } \\
\text { (CK-MB or LDH or } \\
\text { CK), Q-waves, } \\
\text { scintiscan, sudden } \\
\text { unexplained } \\
\text { death within } 72 \mathrm{hr}\end{array}$ \\
\hline $\begin{array}{l}\text { Berger, et al, } \\
1990^{28}\end{array}$ & $\begin{array}{l}\text { Prospective } \\
\text { consecutive }\end{array}$ & 278 & 36 & 57 & 69 & $\mathrm{CCU}$ & $\begin{array}{l}\text { Admitted to the } \\
\text { hospital, complaining } \\
\text { chiefly of chest pain }\end{array}$ & $\begin{array}{l}\text { Trauma, } \\
\text { transferred } \\
\text { from other } \\
\text { hospital with a } \\
\text { diagnosis }\end{array}$ & $\begin{array}{l}\text { Chest pain, ECG } \\
\text { changes indicating } \\
\text { myocardial infarction, } \\
\text { significant CK } \\
\text { elevation } \\
\end{array}$ \\
\hline $\begin{array}{l}\text { Jonsbu, et al, } \\
1991^{29}\end{array}$ & $\begin{array}{l}\text { Prospective } \\
\text { consecutive }\end{array}$ & 200 & 37 & $?$ & $?$ & $\mathrm{CCU}$ & $\begin{array}{l}\text { Admitted to hospital } \\
\text { with suspected acute } \\
\text { heart disease }\end{array}$ & $\begin{array}{l}\text { Unable to give } \\
\text { reliable medical } \\
\text { history }\end{array}$ & $\begin{array}{l}\text { Clinical history, ECD } \\
\text { signs, enzyme activity, } \\
\text { ventriculography, } \\
\text { scintigraphy, autopsy }\end{array}$ \\
\hline $\begin{array}{l}\text { Gaston- } \\
\text { Johansson, } \\
\text { et al,199130 }\end{array}$ & $\begin{array}{l}\text { Prospective } \\
\text { consecutive }\end{array}$ & 94 & 40 & $?$ & 71 & $\mathrm{CCU}$ & $\begin{array}{c}\text { Chest pain } \\
\text { suggesting AMI }\end{array}$ & $\begin{array}{l}>75 \mathrm{yr} \text {, cardiogenic } \\
\text { shock }\end{array}$ & $\begin{array}{l}\text { Two of: typical clinical } \\
\text { symptoms and chest } \\
\text { pain > } 15 \text { mins, AAT or } \\
\text { CK elevations, Q } \\
\text { waves ST elevation } \\
\text { or T inversion }\end{array}$ \\
\hline
\end{tabular}




\section{Appendix 3 continued: Characteristics of acute myocardial infarction (AMI) included studies.}

\begin{tabular}{|c|c|c|c|c|c|c|}
\hline $\begin{array}{l}\text { Hartford, et al, } \\
1993^{31}\end{array}$ & $\begin{array}{l}\text { Prospective } \\
\text { consecutive }\end{array}$ & 226 & 48 & ? & ? & $\mathrm{CCU}$ \\
\hline
\end{tabular}

suspected AMI
Very poor Two of three:
clinical condition, chest pain >
does not $15 \mathrm{~min}$,

understand Swedish aminotransferase,

new Q-waves

in two leads

\begin{tabular}{|c|c|c|c|c|c|c|c|c|c|}
\hline $\begin{array}{l}\text { Everts, et al, } \\
1996^{33}\end{array}$ & $\begin{array}{l}\text { Prospective } \\
\text { consecutive }\end{array}$ & 902 & 50 & 64 & 71 & $\mathrm{CCU}$ & $\begin{array}{c}\text { Chest pain } \\
\text { with possible AMI }\end{array}$ & $\begin{array}{c}\text { Hypotension, } \\
\text { severe congestive } \\
\text { heart failure, } \\
\text { severe UA, } \\
\text { cognitive } \\
\text { limitation, language }\end{array}$ & $\begin{array}{l}\text { Two of three: } \\
\text { chest pain } \\
>15 \text { min, } \\
\text { aminotranferase, } \\
\text { new Q-waves in } \\
\text { two leads }\end{array}$ \\
\hline $\begin{array}{l}\text { Pfister, et al, } \\
1997^{34}\end{array}$ & $\begin{array}{l}\text { Prospective } \\
\text { consecutive }\end{array}$ & 327 & 18 & 64 & 65 & ED & $\begin{array}{l}\text { Chest pain } \\
\text { (>10 min), irradiation } \\
\text { (epigastric, jaw, } \\
\text { L extremity) } \\
\text { during angina, } \\
\text { dyspnoea, non- } \\
\text { traumatic or toxic } \\
\text { cardiac arrest }\end{array}$ & $<20 \mathrm{yr}$, trauma & $\begin{array}{l}\text { At least two } \\
\text { of: history, } \\
\text { ECG, CK-MB }\end{array}$ \\
\hline $\begin{array}{l}\text { Lopez-Jiminez } \\
\text { et al, } 1998^{35}\end{array}$ & $\begin{array}{l}\text { Prospective } \\
\text { consecutive }\end{array}$ & 2694 & 6 & $?$ & 45 & ED & $\begin{array}{l}\text { Chief complaint } \\
\text { of chest pain }\end{array}$ & $\begin{array}{c}\text { Local trauma, } \\
\text { abnormalities on } \\
\text { chest X-ray, <30 yr, } \\
>4 \text { visit, prior AMl, } \\
\text { A, PTCA, bypass }\end{array}$ & $\begin{array}{c}\text { One of: } \\
\text { characteristics } \\
\text { evolution of enzyme } \\
\text { levels (CK-MB or } \\
\text { LDH or CK), Q- } \\
\text { waves, scintiscan, } \\
\text { sudden unexplained } \\
\text { death within } 72 \mathrm{hr}\end{array}$ \\
\hline $\begin{array}{l}\text { Pope, et al, } \\
1998^{36}\end{array}$ & $\begin{array}{l}\text { Prospective } \\
\text { consecutive }\end{array}$ & 10689 & 8 & 59 & 52 & ED & $\begin{array}{l}\text { Chief complaint } \\
\text { chest, left arm, } \\
\text { jaw or epigastric } \\
\text { pain or discomfort, } \\
\text { dyspnoea, dizziness, } \\
\text { palpitations or other } \\
\text { symptoms suggestive } \\
\text { of acute ischemia }\end{array}$ & $\begin{array}{l}\quad<30 y r, 18 y r \\
\text { if suspected to } \\
\text { have used cocaine }\end{array}$ & $\begin{array}{l}\text { WHO criteria } \\
\text { for AMl }\end{array}$ \\
\hline $\begin{array}{l}\text { Graff, et al, } \\
2000^{37}\end{array}$ & $\begin{array}{l}\text { Prospective } \\
\text { consecutive }\end{array}$ & 10678 & 2 & $?$ & $?$ & ED & $\begin{array}{l}\text { All patients } \\
\text { with possible } \\
\text { AMI were a } \\
\text { rapid ECG } \\
\text { was performed }\end{array}$ & No & $\begin{array}{l}\text { ICD-9-CM 410. } \\
01 / 11 / 21 / 31 / 41 / \\
51 / 61 / 71 / 81 / 91\end{array}$ \\
\hline $\begin{array}{l}\text { Herlitz, et al, } \\
2002^{39}\end{array}$ & $\begin{array}{l}\text { Retrospective } \\
\text { consecutive }\end{array}$ & 930 & 14 & 71 & 51 & Para & $\begin{array}{c}\text { Chest pain or } \\
\text { slightest suspicion } \\
\text { of an acute coronary } \\
\text { syndrome }\end{array}$ & No & $\begin{array}{c}\text { Two of: chest } \\
\text { pain >15 min, CK } \\
\text { more than twice } \\
\text { upper limit, Q-waves }\end{array}$ \\
\hline $\begin{array}{l}\text { Goodacre, et al, } \\
2002^{40}\end{array}$ & $\begin{array}{l}\text { Prospective } \\
\text { consecutive }\end{array}$ & 893 & 4 & 53 & 62 & CPOU & $\begin{array}{c}\text { Chest pain } \\
\text { (patients at low risk) }\end{array}$ & $\begin{array}{c}<25 \mathrm{yr} \text {, trauma, new } \\
\text { ECG changes } \\
\text { consistent with ischemi } \\
\text { comorbidity necessitatir } \\
\text { hospitalisation, definite } \\
\text { unstable angina }\end{array}$ & $\begin{array}{l}\text { WHO criteria } \\
\text { for AMl } \\
\text { ia, } \\
\text { ng } \\
\text { e }\end{array}$ \\
\hline $\begin{array}{l}\text { Baxt, et al, } \\
2002^{41}\end{array}$ & $\begin{array}{c}\text { Prospective } \\
\text { 16/ day }\end{array}$ & 2204 & 6 & 53 & 40 & ED & $\begin{array}{l}\text { Anterior chest pain } \\
\text { prompting an ECG }\end{array}$ & $<24 \mathrm{yr}$ & $\begin{array}{c}\text { European Society } \\
\text { of Cardiology criteria }\end{array}$ \\
\hline $\begin{array}{l}\text { Albarran, et al, } \\
2002^{42}\end{array}$ & $\begin{array}{l}\text { Prospective } \\
\text { consecutive }\end{array}$ & 541 & 48 & $?$ & 68 & $\mathrm{CCU}$ & $\begin{array}{l}\text { Acute chest } \\
\text { pain }\end{array}$ & $\begin{array}{c}\text { Pain >24 hr, } \\
<18 \text { yr, no English }\end{array}$ & $\begin{array}{l}\text { Troponin I }>6 \mathrm{ng} / \mathrm{ml} \\
\text { and ECG changes }\end{array}$ \\
\hline $\begin{array}{l}\text { Svensson, et al, } \\
2003^{44}\end{array}$ & $\begin{array}{l}\text { Prospective } \\
\text { consecutive }\end{array}$ & 538 & 29 & 69 & 58 & Para & $\begin{array}{l}\text { Chest pain or } \\
\text { discomfort }>15 \mathrm{~min} \text {, } \\
\text { within last } 6 \mathrm{hr} \text {, } \\
\text { dyspnoea, or any } \\
\text { ndition suggesting acu } \\
\text { coronary syndrome }\end{array}$ & Lung disease & $\begin{array}{c}\text { Two of: typical } \\
\text { symptoms, Q- } \\
\text { waves, CK-MB> } \\
10 \mathrm{ng} / \mathrm{ml} \text { or troponin } \\
>0.05 \mathrm{ng} / \mathrm{ml}\end{array}$ \\
\hline
\end{tabular}

${ }^{a}$ The patients of the first article are part of the second study. The signs and symptoms discussed in the two studies are different. Car = cardiologist; CCU = coronary care unit or admitted to hospital, $C P O U=$ chest pain observation unit, ECD = electrocardiogram, ED = emergency department, Para $=$ paramedics of an ambulance. $A=$ angina. $A A T=$ aspartate aminotransferase. $A M I=$ acute myocardial infarction. $C K=$ creatine kinase. $C K-M B=C K$ isoenzyme. $E C G=$ echocardiogram. $G O T=$ aspartate aminotransferase. GPT = alanine transferase. ICD = International Classification of Diseases. $L D H=$ lactate dehydrogenase. $L D H 1=$ lactate dehydrogenase isoenzyme 1. UA = unstable angina. WHO = World Health Organization. 
Appendix 4. Characteristics of acute coronary syndrome = acute myocardial infarction + unstable angina included studies.

\begin{tabular}{|c|c|c|c|c|c|c|c|c|c|}
\hline Study & Design & $\begin{array}{l}\text { Sample } \\
\text { size }\end{array}$ & $\%$ ACS & $\begin{array}{l}\text { Mean } \\
\text { age }\end{array}$ & $\begin{array}{c}\% \\
\text { Males }\end{array}$ & Setting & Inclusion & Exclusion & $\begin{array}{l}\text { Reference } \\
\text { Standard }\end{array}$ \\
\hline $\begin{array}{l}\text { Lee, et al, } \\
1985^{23}\end{array}$ & $\begin{array}{l}\text { Prospective } \\
\text { consecutive }\end{array}$ & 596 & 41 & 56 & 48 & ED & $\begin{array}{l}\text { Chief complaint } \\
\text { of anterior, } \\
\text { precordial or left } \\
\text { lateral chest pain }\end{array}$ & $\begin{array}{l}\text { Local trauma, } \\
\text { abnormalities on } \\
\text { chest X-ray, }<25 \mathrm{yr}\end{array}$ & $\begin{array}{c}\text { AMl: one of } \\
\text { characteristic } \\
\text { evolution of enzyme } \\
\text { levels (CK-MB, } \\
\text { LDH, CK), Q-waves, } \\
\text { scintiscan. UA: chest } \\
\text { pain worse or new } \\
\text { and diagnosis was } \\
\text { made by a senior }\end{array}$ \\
\hline
\end{tabular}



by T-inversion

(at least two

leads), CPK-MB,

LDH ration, autopsy

pyrophosphate scan

UA: no

\begin{tabular}{|c|c|c|c|c|c|c|c|}
\hline $\begin{array}{l}\text { Grijseels, } \\
\text { et al, } 1995^{32}\end{array}$ & $\begin{array}{l}\text { Prospective } \\
\text { consecutive }\end{array}$ & 1005 & 42 & 67 & 54 & GP & $\begin{array}{c}\text { Symptoms of } \\
\text { possible cardiac } \\
\text { origin seen by GP }\end{array}$ \\
\hline
\end{tabular}

and transferred

AMI: standard

history, ECG,

enzyme criteria

UA: angina with

increasing frequency

and severity and new

recent onset with

documentation of ST

-T changes at rest,

abnormal stress test

or coronary

arteriogram

\begin{tabular}{|c|c|c|c|c|c|c|c|c|c|}
\hline $\begin{array}{l}\text { Pope, et al, } \\
1998^{36}\end{array}$ & $\begin{array}{l}\text { Prospective } \\
\text { consecutive }\end{array}$ & 10689 & 23 & 59 & 52 & ED & $\begin{array}{l}\text { Chief complaint } \\
\text { of chest, left arm, } \\
\text { jaw or epigastric } \\
\text { pain or discomfort, } \\
\text { dyspnoea, dizziness, } \\
\text { palpitations or other } \\
\text { symptoms suggestive } \\
\text { of acute ischemia }\end{array}$ & $\begin{array}{l}<30 \mathrm{yr}, 18 \mathrm{yr} \text { if } \\
\text { suspected to have } \\
\text { used cocaine } \\
\text { e }\end{array}$ & $\begin{array}{c}\text { AMI: } \\
\text { WHO criteria } \\
\text { for AMI } \\
\text { UA: Canadian } \\
\text { Cardiovascular } \\
\text { Society } \\
\text { classification criteria }\end{array}$ \\
\hline $\begin{array}{l}\text { Milner, et al, } \\
2001^{38}\end{array}$ & $\begin{array}{l}\text { Prospective } \\
\text { consecutive }\end{array}$ & 531 & 40 & 60 & 53 & ED & $\begin{array}{c}>45 \mathrm{yr} \text { and one } \\
\text { symptom suggestive } \\
\text { of ACS, or } 18-44 \mathrm{yr} \\
\text { if diabetes and two } \\
\text { risk factors }\end{array}$ & $\begin{array}{c}<45 \mathrm{yr} \\
\text { without diabetes } \\
\text { or }<18 \mathrm{yr} \\
\text { with diabetes }\end{array}$ & $\begin{array}{l}\text { AMI: elevated } \\
\text { cardiac enzymes } \\
\text { (CK-MB). UA: } \\
\text { ECG changes } \\
\text { (ST, T) and no } \\
\text { cardiac enzymes } \\
\text { elevation }\end{array}$ \\
\hline $\begin{array}{l}\text { Herlitz, et al, } \\
2002^{39}\end{array}$ & $\begin{array}{l}\text { Retrospective } \\
\text { consecutive }\end{array}$ & 930 & 30 & 71 & 51 & Para & $\begin{array}{l}\text { Chest pain or } \\
\text { slightest suspicion } \\
\text { of an acute } \\
\text { coronary syndrome }\end{array}$ & $\mathrm{cr}$ & $\begin{array}{c}\text { AMI: two of } \\
\text { chest pain>15 min, CK } \\
\text { more than twice } \\
\text { upper limit, Q-wave } \\
\text { A: according to } \\
\text { clinical judgement }\end{array}$ \\
\hline $\begin{array}{l}\text { Goodacre, et al, } \\
2002^{40}\end{array}$ & $\begin{array}{l}\text { Prospective } \\
\text { consecutive }\end{array}$ & 893 & 9 & 53 & 62 & CPOU & $\begin{array}{l}\text { Chest pain } \\
\text { (patients at low risk) }\end{array}$ & $\begin{array}{l}<25 \mathrm{yr}, \\
\text { trauma, new ECG } \\
\text { changes consistent } \\
\text { with ischemia, } \\
\text { omorbidity necessitating } \\
\text { hospitalisation, definite } \\
\text { unstable angina }\end{array}$ & $\begin{array}{l}\text { AMI: WHO criteria } \\
\text { for AMI. ACS: present } \\
\text { or in following } \\
6 \text { months: AMI, } \\
\text { cardiac death, } \\
\text { arrhythmia or } \\
\text { revascularisation }\end{array}$ \\
\hline $\begin{array}{l}\text { Vodopiutz, et al, } \\
2002^{43}\end{array}$ & $\begin{array}{l}\text { Prospective } \\
\text { at random }\end{array}$ & 92 & 47 & 62 & 48 & $\mathrm{CCU}$ & $\begin{array}{l}\text { Admitted because } \\
\text { of chest pain as } \\
\text { main symptom }\end{array}$ & $\begin{array}{l}\text { Refused, too sick, } \\
\text { language problems }\end{array}$ & $\begin{array}{l}\text { AMI: angio, autopsy, } \\
\text { scintigraphy, } \\
\text { echocardio, ECG } \\
\text { and enzyme } \\
\text { kinetics UA: no }\end{array}$ \\
\hline
\end{tabular}




\section{Appendix 4 continued. Characteristics of acute coronary syndrome = acute myocardial infarction + unstable angina included studies.}

\begin{tabular}{|c|c|c|c|c|c|c|c|c|c|}
\hline $\begin{array}{l}\text { Svensson, et al, } \\
2003^{44}\end{array}$ & $\begin{array}{l}\text { Prospective } \\
\text { consecutive }\end{array}$ & 538 & 57 & 69 & 58 & Para & $\begin{array}{l}\text { Due to chest } \\
\text { pain or discomfort } \\
>15 \mathrm{~min} \text {, within } \\
\text { last } 6 \mathrm{hr} \text {, dyspnoea, } \\
\text { or any condition } \\
\text { suggesting acute } \\
\text { CS }\end{array}$ & $\begin{array}{l}\text { Lung } \\
\text { disease }\end{array}$ & $\begin{array}{l}\text { AMl: two of: } \\
\text { typical symptoms, } \\
\text { Q-waves, CK-MB } \\
>10 \mathrm{ng} / \mathrm{ml} \text { or } \\
\text { troponin }>0.05 \mathrm{ng} / \mathrm{ml} \\
\text { Myocardial ischemia: } \\
\text { dynamic changes } \\
\text { ECG, no increase } \\
\text { biochemical markers }\end{array}$ \\
\hline $\begin{array}{l}\text { Goodacre, et al, } \\
2003^{45}\end{array}$ & $\begin{array}{l}\text { Prospective } \\
\text { consecutive }\end{array}$ & 972 & 8 & 50 & 64 & ED & $\begin{array}{l}\text { ‘Undifferentiated } \\
\text { chest } \\
\text { pain' all patients } \\
\text { attending } \\
\text { with chest pain } \\
\text { or related } \\
\text { complaint (low risk) }\end{array}$ & $\begin{array}{l}\text { Evidence of } \\
\text { ACS (ECG or } \\
\text { clear clinical) } \\
\text { requiring admission, } \\
\text { clear non-cardiac } \\
\text { cause no } \\
\text { informed consent }\end{array}$ & $\begin{array}{l}\text { ACS: any elevation } \\
\text { of T (after } 2 \text { days) } \\
\text { or after } 30 \text { days: } \\
\text { cardiac death, non- } \\
\text { fatal myocardial } \\
\text { infarction, new- } \\
\text { onset heart failure, } \\
\text { life-threatening } \\
\text { arrhythmia } \\
\text { or coronary } \\
\text { revascularisation } \\
\text { procedure }\end{array}$ \\
\hline $\begin{array}{l}\text { Christenson, } \\
\text { et al, 2006 }\end{array}$ & $\begin{array}{l}\text { Prospective } \\
7 \mathrm{am}-10 \mathrm{pm}\end{array}$ & 769 & 21 & 58 & 62 & ED & $\begin{array}{l}\text { Primary complaint } \\
\text { of anterior or } \\
\text { lateral chest pain }\end{array}$ & $\begin{array}{c}<25 \mathrm{yr} \text {, traumatic } \\
\text { or XR- evident } \\
\text { cause, enrolled } \\
\text { in study } 30 \text { days } \\
\text { previously, } \\
\text { communication } \\
\text { problems, no } \\
\text { fixed address in } \\
\text { British Columbia, } \\
\text { without available } \\
\text { telephone } \\
\text { contact }\end{array}$ & 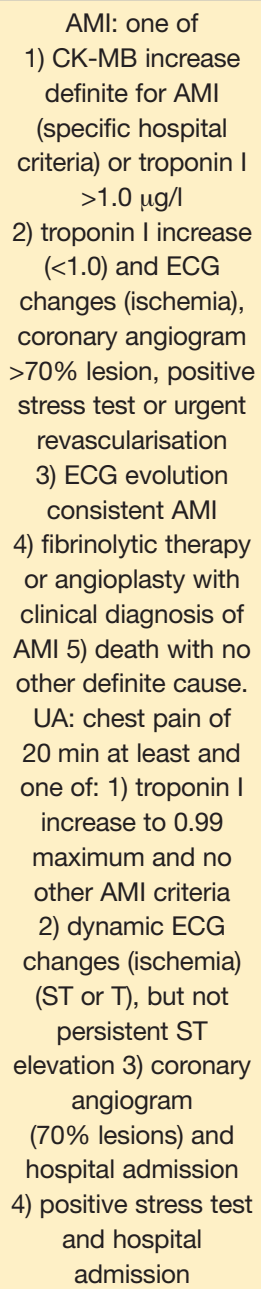 \\
\hline
\end{tabular}

Car = cardiologist; $C C U$ = coronary care unit or admitted to hospital, $C P O U=$ chest pain observation unit, ECD = electrocardiogram, ED = emergency department, Para = paramedics of an ambulance. $A C S=$ acute coronary syndrome. $A M I=$ acute myocardial infarction. $C K=$ creatine kinase. $C K-M B=C K$ isoenzyme. CS = coronary syndrome. $E C G=$ echocardiogram. $L D H=$ lactate dehydrogenase. $U A=$ unstable angina. WHO =World Health Organization. $X R=X$-rays. 
Appendix 5. Pooled sensitivity, specificity, positive and negative likelihood ratios, odds ratios of signs and symptoms for acute myocardial infarction in patient groups.

\begin{tabular}{|c|c|c|c|c|c|c|c|}
\hline \multirow[b]{2}{*}{ Symptom } & & \multicolumn{3}{|c|}{$\begin{array}{l}\text { Acute myocardial infarction } \\
\text { Non-selected patients }\end{array}$} & \multicolumn{3}{|c|}{$\begin{array}{l}\text { Acute myocardial infarction } \\
\text { Selected patients }\end{array}$} \\
\hline & & & $95 \% \mathrm{Cl}$ & $\mathrm{I}^{\mathrm{a}}(\%)$ & & $95 \% \mathrm{Cl}$ & $\mathrm{I}^{\mathrm{a}}(\%)$ \\
\hline \multicolumn{8}{|c|}{ Pain in left arm and/or shoulder } \\
\hline Not selected ${ }^{41}$ & Sensitivity & 33 & 25.4 to 41.8 & - & 54 & 50.2 to 56.9 & 0 \\
\hline \multirow[t]{4}{*}{ Selected ${ }^{19,28,30,33,42}$} & Specificity & 76.3 & 74.5 to 78.2 & - & 65 & 56.4 to 72.8 & 87 \\
\hline & $\mathrm{LR}+$ & 1.42 & 1.10 to 1.83 & - & 1.49 & 1.20 to 1.85 & 71 \\
\hline & LR- & 0.87 & 0.77 to 0.99 & - & 0.76 & 0.66 to 0.88 & 57 \\
\hline & OR & 1.631 & 12 to 2.39 & - & 2.00 & 1.39 to 2.88 & 65 \\
\hline \multicolumn{8}{|c|}{ Pain in right arm and/or shoulder } \\
\hline Not selected ${ }^{24}$ & Sensitivity & 15 & 5.9 to 23.7 & - & 32 & 25.1 to 40.8 & 77 \\
\hline \multirow[t]{4}{*}{ Selected ${ }^{19,28,30,33,42}$} & Specificity & 95 & 92.8 to 97.0 & - & 86 & 78.4 to 91.2 & 85 \\
\hline & $\mathrm{LR}+$ & 2.89 & 1.40 to 5.98 & - & 2.35 & 1.44 to 3.84 & 80 \\
\hline & LR- & 0.90 & 0.81 to 1.00 & - & 0.81 & 0.66 to 1.00 & 96 \\
\hline & OR & 3.22 & 1.41 to 7.36 & - & 3.09 & 1.63 to 5.85 & 80 \\
\hline \multicolumn{8}{|l|}{ Pain in both arms } \\
\hline Not selected (n/a) & Sensitivity & & & & 32 & 25.1 to 40.8 & 77 \\
\hline \multirow{4}{*}{ Selected ${ }^{19}$} & Specificity & & & & 86 & 78.4 to 91.2 & 85 \\
\hline & $\mathrm{LR}+$ & & & & 2.35 & 1.44 to 3.84 & 80 \\
\hline & LR- & & & & 0.81 & 0.66 to 1.00 & 96 \\
\hline & OR & & & & 3.09 & 1.63 to 5.85 & 80 \\
\hline \multicolumn{8}{|l|}{ Pain in neck } \\
\hline Not selected ${ }^{41}$ & Sensitivity & 14 & 8.2 to 20.4 & - & 24 & 18.3 to 30.2 & 65 \\
\hline \multirow[t]{4}{*}{ Selected ${ }^{30,33,42}$} & Specificity & 90 & 89.0 to 91.6 & - & 75 & 71.6 to 77.7 & 0 \\
\hline & $\mathrm{LR}+$ & 1.48 & 0.94 to 2.31 & - & 0.99 & 0.83 to 1.17 & 0 \\
\hline & LR- & 0.95 & 0.88 to 1.02 & - & 1.00 & 0.95 to 1.07 & 0 \\
\hline & OR & 1.55 & 0.92 to 2.61 & - & 0.98 & 0.78 to 1.23 & 0 \\
\hline \multicolumn{8}{|l|}{ Pain in back } \\
\hline Not selected (n/a) & Sensitivity & & & & 25 & 22.0 to 28.2 & 0 \\
\hline \multirow[t]{4}{*}{ Selected ${ }^{30,33,42}$} & Specificity & & & & 71 & 66.4 to 75.6 & 45 \\
\hline & $\mathrm{LR}+$ & & & & 0.84 & 0.62 to 1.14 & 59 \\
\hline & LR- & & & & 1.07 & 0.96 to 1.19 & 60 \\
\hline & OR & & & & 0.78 & 0.52 to 1.19 & 59 \\
\hline \multicolumn{8}{|l|}{ Epigastric pain } \\
\hline Not selected ${ }^{23}$ & Sensitivity & 10 & 3.9 to 15.3 & - & 5 & 2.1 to 10.8 & 89 \\
\hline Selected ${ }^{34,36,37,39}$ & Specificity & 93 & 91.1 to 95.2 & - & 91 & 85.0 to 95.4 & 99 \\
\hline & $\mathrm{LR}+$ & 1.44 & 0.73 to 2.83 & - & 0.73 & 0.61 to 0.87 & 0 \\
\hline & LR- & 0.97 & 0.91 to 1.04 & - & 1.04 & 1.02 to 1.05 & 0 \\
\hline & $\mathrm{OR}$ & 1.49 & 0.71 to 3.12 & - & 0.69 & 0.57 to 0.85 & 0 \\
\hline Oppressive pain & & & & & & & \\
\hline Not selected ${ }^{23,24,27,35,41}$ & Sensitivity & 60 & 53.7 to 66.0 & 77 & 77 & 71.3 to 81.2 & 0 \\
\hline Selected ${ }^{28,29,31}$ & Specificity & 58 & 55.0 to 60.2 & 87 & 35 & 28.7 to 41.3 & 48 \\
\hline & $\mathrm{LR}+$ & 1.42 & 1.32 to 1.53 & 36 & 1.79 & 1.07 to 1.30 & 0 \\
\hline & LR- & 0.69 & 0.61 to 0.80 & 64 & 0.70 & 0.52 to 0.86 & 0 \\
\hline & OR & 2.06 & 1.60 to 2.53 & 51 & 1.77 & 1.25 to 2.51 & 0 \\
\hline Vomiting and/or nausea & & & & & & & \\
\hline Not selected ${ }^{24,36,39,41}$ & Sensitivity & 34 & 25.3 to 44.1 & 84 & 29 & 12.5 to 51.5 & 97 \\
\hline Selected ${ }^{20,22,26,28,29}$ & Specificity & 77 & 71.1 to 81.3 & 97 & 81 & 76.6 to 85.1 & 73 \\
\hline & LR+ & 1.41 & 1.17 to 1.72 & 64 & 1.42 & 0.76 to 2.64 & 92 \\
\hline & LR- & 0.83 & 0.83 to 0.96 & 52 & 0.82 & 0.66 to 1.03 & 94 \\
\hline & OR & 1.62 & 1.22 ro 2.14 & 59 & 1.73 & 0.71 to 4.12 & 93 \\
\hline Sweating & & & & & & & \\
\hline Not selected ${ }^{21,24,27,39,41,44}$ & Sensitivity & 45 & 36.0 to 54.0 & 91 & 41 & 22.9 to 60.5 & 95 \\
\hline Selected ${ }^{20,22,29,31}$ & Specificity & 84 & 78.6 to 88.0 & 97 & 85 & 69.2 to 94.7 & 98 \\
\hline & LR+ & 2.92 & 1.97 to 4.32 & 95 & 2.44 & 1.42 to 4.20 & 81 \\
\hline & LR- & 0.69 & 0.60 to 0.78 & 81 & 0.72 & 0.56 to 0.91 & 90 \\
\hline & OR & 4.54 & 2.47 to 8.36 & 94 & 3.81 & 1.88 to 7.70 & 83 \\
\hline Absence of chest wall ter & & & & & & & \\
\hline Not selected ${ }^{23,24,27,35}$ & Sensitivity & 92 & 85.5 to 96.4 & 89 & & & \\
\hline Selected (n/a) & Specificity & 36 & 20.5 to 51.8 & 99 & & & \\
\hline & LR+ & 1.47 & 1.23 to 1.75 & 97 & & & \\
\hline & LR- & 0.23 & 0.18 to 0.29 & 0 & & & \\
\hline & OR & 0.17 & 0.12 to 0.23 & 26 & & & \\
\hline
\end{tabular}

$\mathrm{a} / 2=100 \% \times(\mathrm{Q}-\mathrm{df}) / \mathrm{Q}$, where $\mathrm{Q}$ is Cochran's heterogeneity statistic and df the degrees of freedom. $L R+=$ positive likelihood ratio. $L R-=$ negative likelihood ratio. $\mathrm{OR}=$ odds ratio 
Appendix 6. Pooled sensitivity, specificity, positive and negative likelihood ratios, odds ratios of signs and symptoms for acute coronary syndrome in patients groups.

\begin{tabular}{|c|c|c|c|c|c|c|c|}
\hline \multirow[b]{2}{*}{ Symptom } & & \multicolumn{3}{|c|}{$\begin{array}{l}\text { Acute coronary syndrome } \\
\text { Non-selected patients }\end{array}$} & \multicolumn{3}{|c|}{$\begin{array}{l}\text { Acute coronary syndrome } \\
\text { Selected patients }\end{array}$} \\
\hline & & & $95 \% \mathrm{Cl}$ & $\mathrm{I}^{\mathrm{2a}}(\%)$ & & $95 \% \mathrm{Cl}$ & $\mathrm{I}^{\mathrm{a}}(\%)$ \\
\hline \multicolumn{8}{|c|}{ Pain in left arm and/or shoulder } \\
\hline Not selected ${ }^{38,45,46}$ & Sensitivity & 38 & 18.6 to 59.5 & 95 & & & \\
\hline \multirow{4}{*}{ Selected (n/a) } & Specificity & 71 & 56.9 to 82.6 & 97 & & & \\
\hline & LR+ & 1.30 & 1.13 to 1.47 & 0 & & & \\
\hline & LR- & 0.88 & 0.78 to 1.00 & 58 & & & \\
\hline & OR & 1.50 & 1.19 to 1.90 & 0 & & & \\
\hline \multicolumn{8}{|c|}{ Pain in right arm and/or shoulder } \\
\hline Not selected ${ }^{45}$ & Sensitivity & 18 & 9.6 to 26.2 & - & 23 & 10.6 to 35.9 & - \\
\hline \multirow[t]{4}{*}{ Selected ${ }^{43}$} & Specificity & 95 & 93.8 to 96.1 & - & 94 & 87.2 to 100 & - \\
\hline & $\mathrm{LR}+$ & 3.78 & 2.17 to 6.60 & - & 3.80 & 1.12 to 12.91 & - \\
\hline & LR- & 0.86 & 0.77 to 0.96 & - & 0.82 & 0.98 to 0.98 & - \\
\hline & OR & 4.40 & 2.29 to 8.48 & - & 46.5 & 1.19 to 18.20 & - \\
\hline \multicolumn{8}{|l|}{ Pain in neck } \\
\hline Not selected ${ }^{46}$ & Sensitivity & 35 & 27.9 to 42.4 & - & & & \\
\hline \multirow[t]{4}{*}{ Selected (n/a) } & Specificity & 76 & 72.2 to 79.1 & - & & & \\
\hline & $\mathrm{LR}+$ & 1.44 & 1.12 to 1.86 & - & & & \\
\hline & LR- & 0.86 & 0.76 to 0.97 & - & & & \\
\hline & OR & 1.69 & 1.16 to 2.44 & - & & & \\
\hline \multicolumn{8}{|l|}{ Pain in back } \\
\hline Not selected ${ }^{38,45}$ & Sensitivity & 13 & 2.8 to 34.3 & 86 & 29 & 15.3 to 43.2 & - \\
\hline Selected $^{43}$ & Specificity & 76 & 26.7 to 98.6 & 98 & 49 & 35.0 to 63.0 & - \\
\hline \multirow{3}{*}{$\mathrm{ACS}^{38,43,45}$} & LR+ & 1.49 & 0.62 to 3.56 & 80 & 0.57 & 0.33 to 0.99 & - \\
\hline & LR- & 0.93 & 0.77 to 1.13 & 87 & 1.44 & 1.02 to 2.04 & - \\
\hline & OR & 1.59 & 0.58 to 4.37 & 80 & 0.40 & 0.17 to 0.90 & - \\
\hline \multicolumn{8}{|l|}{ Epigastric pain } \\
\hline Not selected ${ }^{23,36,39,45}$ & Sensitivity & 12 & 5.4 to 20.8 & 97 & & & \\
\hline \multirow[t]{4}{*}{ Selected (n/a) } & Specificity & 89 & 82.9 to 94.1 & 98 & & & \\
\hline & $\mathrm{LR}+$ & 1.05 & 0.35 to 3.20 & 97 & & & \\
\hline & LR- & 0.98 & 0.88 to 1.08 & 97 & & & \\
\hline & OR & 1.08 & 0.31 to 3.74 & 97 & & & \\
\hline \multicolumn{8}{|l|}{ Oppressive pain ${ }^{56}$} \\
\hline Not selected ${ }^{23}$ & Sensitivity & 56 & 49.7 to 62.1 & - & 79 & 66.9 to 91.2 & - \\
\hline \multirow{4}{*}{ Selected ${ }^{43}$} & Specificity & 67 & 61.8 to 71.7 & - & 39 & 25.1 to 52.4 & - \\
\hline & LR+ & 1.68 & 1.40 to 2.02 & - & 1.29 & 0.99 to 1.69 & - \\
\hline & LR- & 0.66 & 0.56 to 0.77 & - & 0.54 & 0.27 to 1.06 & - \\
\hline & OR & 2.54 & 1.82 to 3.56 & - & 2.39 & 0.94 to 6.08 & - \\
\hline \multicolumn{8}{|l|}{ Vomiting and/or nausea } \\
\hline Not selected ${ }^{25,36,38,39,44,4}$ & Sensitivity & 26 & 20.7 to 32.2 & 91 & & & \\
\hline \multirow[t]{4}{*}{ Selected (n/a) } & Specificity & 82 & 74.1 to 88.4 & 98 & & & \\
\hline & LR+ & 1.32 & 1.09 to 1.65 & 68 & & & \\
\hline & LR- & 0.93 & 0.89 to 0.96 & 35 & & & \\
\hline & OR & 1.43 & 1.14 to 1.81 & 63 & & & \\
\hline Sweating & & & & & & & \\
\hline Not selected ${ }^{32,38,39,44}$ & Sensitivity & 43 & 32.2 to 64.9 & 98 & & & \\
\hline Selected (n/a) & Specificity & 68 & 44.0 to 86.5 & 99 & & & \\
\hline & LR+ & 1.34 & 1.09 to 1.65 & 76 & & & \\
\hline & LR- & 0.85 & 0.79 to 0.92 & 40 & & & \\
\hline & OR & 1.65 & 1.39 to 1.95 & 0 & & & \\
\hline Absence of chest-wall & & & & & & & \\
\hline Not selected ${ }^{23,24}$ & Sensitivity & 94 & 91.4 to 96.1 & 0 & & & \\
\hline Selected (n/a) & Specificity & 33 & 19.7 to 47.9 & 96 & & & \\
\hline & LR+ & 1.41 & 1.12 to 1.78 & 94 & & & \\
\hline & LR- & 0.17 & 0.11 to 0.26 & 0 & & & \\
\hline & OR & 0.12 & 7.0 to 21.0 & 34 & & & \\
\hline
\end{tabular}

Note: Pain in both arms - not applicable. ${ }^{a}{ }^{2}=100 \% \times(Q-d f) / Q$, where $Q$ is Cochran's heterogeneity statistic and df the degrees of freedom. ACS $=$ acute coronary syndrome. $L R+=$ positive likelihood ratio. $L R-=$ negative likelihood ratio. $O R=$ odds ratio. 